\title{
Knowledge and Attitudes about Ebola Virus Disease among Community Residents in Winchester, Virginia, US
}

\author{
Isha Patel ${ }^{1, *}$, Timothy Jennings ${ }^{1}$, Yun Han², Jason Guy ${ }^{3}$, Isaac Onigbinde ${ }^{4}$, Eric Kwarteng ${ }^{5}$, \\ Davida Eppes ${ }^{6}$, David Parker ${ }^{7}$, Mark Johnson ${ }^{8}$
}

${ }^{1}$ Department of Pharmacy Practice, Administration and Research, Marshall University, School of Pharmacy (MUSOP), One John Marshall Drive, Huntington, WV, USA.

${ }^{2}$ Department of Internal Medicine, University of Michigan, Ann Arbor, MI, USA.

${ }^{3}$ Department of Pharmacy Practice, College of Pharmacy, The University of Findlay,

Findlay, OH, USA.

${ }^{4}$ CVS Pharmacy, 2 Compass Road, Middle River, MD, USA.

${ }^{5}$ CVS Pharmacy, 66 High Ridge Rd, Stamford, CT, USA.

${ }^{6}$ Tuba City Healthcare Regional Corporation, 167 Main St, Tuba City, AZ, USA.

7UPMC Pinnacle Harrisburg Hospital, 111 S Front St, Harrisburg, PA, USA.

${ }^{8}$ Department of Pharmacy Practice, Bernard J. Dunn School of Pharmacy, Shenandoah University, 1775 N. Sector Court, Winchester, VA, USA.

\begin{abstract}
Background: Educating individuals in the community is an important step in helping to improve response to disease outbreaks. This education can help reduce the spread of misinformation during an outbreak. Unfortunately, there is little information in the literature on what factors play a role in the education of individuals in the community. Methods: This cross-sectional study was designed to identify factors that could contribute to the overall knowledge of community members residing in Winchester, Virginia, US. A survey was provided to members of the community and 375 individuals completed the survey. Knowledge and attitudes regarding Ebola were tested on the survey. A score of 4 represented good knowledge of the Ebola Virus. Logistic regression was used to determine factors that could play a role in community education of Ebola. Results: The results of this study showed that higher age $(O R=2.77, p<0.05)$ and education level (OR $=6.62, p<0.01$ ) were associated with more knowledge regarding the Ebola virus. Additionally, only $11 \%$ of community patients met the study's classification of having good knowledge of the Ebola Virus. A majority of our participants strongly agreed that Ebola is a serious condition and communities should actively participate in controlling the risk of Ebola. Most individuals received their information on Ebola from the internet. Conclusion: The recognition of important factors can help identify patient populations that would benefit the most from enhanced education measures. The low number of patients with a good knowledge of the Ebola virus also presents additional challenges to help better educate and engage the community at large.
\end{abstract}

Key words: Ebola Virus Disease, transmission, public health, disease outbreaks, humans, health knowledge.

\section{INTRODUCTION}

Ebola virus disease (EVD), also known as Ebola hemorrhagic fever or Ebola, is a viral hemorrhagic fever endemic to Africa, mainly the sub-Saharan area. ${ }^{1}$ It is a rare but usually fatal illness, with symptoms appearing 2 to 21 days after infection and consisting of fever, hemorrhage, fatigue, muscle pain, diarrhea and vomiting. ${ }^{2}$ It has been known to mostly infect humans, primates and bats, although bats are carriers and do not show any signs of illness. Ebola is usually trans-
Submission Date: 04-05-2019; Revision Date: 03-06-2019; Accepted Date: 19-06-2019

DOI: 10.5530/ijper.53.3.89 Correspondence: Dr. Isha Patel, PhD Department of Pharmacy Practice, Administration and Research, Marshall University, School of Pharmacy (MUSOP), One John Marshall Drive, Huntington, WV-25755, USA. Phone: +1-304-696-7349 E-mail: pateli@marshall.edu 
mitted by contact with the bodily fluids of an infected human or animal, including saliva, semen, vomit, feces and blood. ${ }^{3}$ There is no vaccine for the prevention of Ebola, (however some vaccines are being investigated) and treatment consists of supportive care and fluid replacement. ${ }^{4,5}$

Ebola gained mass media attention in 2014 after an outbreak in West Africa spread to countries such as Italy and the United States. ${ }^{6}$ This attention caused great concern in the United States, leading to many internet searches and social media posts expressing fear over the deadly disease. It was shown that many individuals highly overestimated their risk of acquiring EVD in the United States. ${ }^{7}$ Despite provided information detailing transmission, low infection rate and low chance of acquiring Ebola, Americans still cited it as one of their major healthcare concerns. ${ }^{8,9}$

To determine how much the populous knows about EVD, several studies have been performed. Most of these studies involve a survey consisting of questions on transmission, symptoms and/or treatment of EVD. ${ }^{10-13}$ A survey of healthcare workers in South India by Ahmad et al. showed a lack of clinical knowledge of EVD, likely due to a lack of research on the subject. The major groups who responded were physicians, pharmacists and nurses and of those three, physicians were reported as having the highest general knowledge. This was attributed to physician's having a much larger clinical role in India. ${ }^{10}$

Another survey of secondary school students in Nigeria by Ilesanmi and Alele showed students had some good general knowledge of EVD. Nigeria was one of the West African countries affected by the 2014-2015 Ebola outbreak, where there were 19 reported cases with 8 confirmed deaths. The indicators for higher scoring were being above the age of 15 , in the senior class and female. A concerning detail the study points out is the lack of knowledge of many routes of transmission, indicating the need for further education. ${ }^{11}$

A study of EVD affected communities in Uganda, a country where EVD is endemic, indicated only about fifty percent of the population had good knowledge of the disease, including symptoms and transmission. However, one of the more concerning details of the study suggests survivors are often ostracized by their fellow community members and some may still believe it is caused by witchcraft, indicating the population may still need further education. ${ }^{12}$

Another study by Kobayashi et al. in 5 Liberian counties of either low or high incidence showed the population in higher incidence countries had a higher general knowledge than their counterparts, although it was still relatively low. Like the Ugandan study, many people were afraid of survivors and sometimes even treatment centers. ${ }^{13}$ These studies suggest the need for additional education on EVD for both high and low risk populations.

Overall, it has been shown that intensive education of healthcare workers is critical to help with patient outcomes. ${ }^{14}$ While there is a great deal of information surrounding EVD education among healthcare professions and healthcare systems there is little information on the overall education of members of the community regarding EVD. Community engagement is a central pillar in response to outbreaks globally. ${ }^{15}$ Community members are important in the overall outcomes and effects of an Ebola outbreak including proper communication and education to reduce the effects of misinformation and poor communication. ${ }^{16,17}$ Community engagement relies on education among community members. To help better understand community knowledge this study focused on the education of community members and what parameters were involved in overall knowledge of EVD.

\section{METHODOLOGY}

\section{Design}

This was a cross sectional study. The study participants included community residents who were patients visiting two clinics in Winchester in the state of Virginia located in US. Convenience sampling technique was employed to recruit participants for the ease of availability and accessibility. Patients in the waiting rooms of the 2 clinics were approached for study participation. Data was collected using a questionnaire adapted from previously published literature. ${ }^{10,18}$ Participation in the study was voluntary.

\section{Survey instrument}

A supervised, self-administered questionnaire was designed and used as a tool to collect the data from the participants during the pilot study and the main survey. The questionnaire was designed after a thorough literature review of the related published studies, after which the questions were short-listed to be included in the final questionnaire. ${ }^{10,18}$ The first version of the questionnaire was sent to subject experts for content validity. The suggested corrections were made to the questionnaire before it was sent to a small sample of $10 \mathrm{HCWs}$ for face validity. The amendments proposed by the participants were then made in view of other published literature. The responses from the pilot study were not included in the final analysis. 
The survey took approximately $10-15$ min to complete and consisted of 17 questions in a web-based survey tool. There were five main sections in the survey, including basic demographics and questions related to EVD transmission, prevention, treatment and perceptions/ attitudes. The survey assessed knowledge of EVD through 4 transmission questions, 4 prevention questions and 2 treatment questions. For these knowledge questions, participants were provided yes/no questions/multiple choice questions. True-false questions were used to increase the efficiency of the reader and because of the dichotomous nature of the questions. Individuals' attitude toward EVD was measured by three attitude statements. These three items used a 5-point Likert scale ( $1=$ strongly agree; $5=$ strongly disagree). A single question was used to determine individuals' source of information about EVD. Demographics were collected at the beginning of the survey.

\section{Data analysis}

Demographic data was recorded. Chi square test was employed to test the association of demographic variables and participant attitudes and knowledge. Each knowledge question was worth 1 point. The participants scored in the range from 0-9. Participants who received $\geq 4$ points (out of a possible 9) were classified as having good knowledge about Ebola virus disease. Multiple logistic regression analysis was performed to find predictors of good knowledge about Ebola virus disease. A $p$ value of less than 0.05 was considered statistically significant. This data management and analysis were performed using SAS 9.4 software. Informed consent was procured prior to data collection. The study was approved by the Shenandoah University IRB committee. Permission for data collection was also procured from the physicians who were in charge of the clinics. The questionnaire responses were recorded anonymously and data was stored in a confidential place while the study was conducted.

\section{RESULTS}

There were 400 community members that were approached for the study and 375 of those individuals participated in the study (response rate $=93.75 \%$ ). In this study, as shown in Table 1, 40.5\% of our study population were male and approximately $40 \%$ of them were aged 50 and above. As expected, about two thirds of the participants were employed, while only $15.5 \%$ of the participants were students. Regarding the education level of the participants, only $11.2 \%$ of our study subjects had received a graduate degree/professional

\begin{tabular}{|c|c|c|}
\hline \multicolumn{2}{|c|}{ Table 1: Baseline characteristics, $\boldsymbol{n}=\mathbf{3 7 5}}$. \\
\hline Demographic variables & $\mathbf{N}$ & $\%$ \\
\hline Male & 152 & 40.5 \\
\hline Age & & \\
\hline $18-29$ & 79 & 21.1 \\
\hline $30-39$ & 70 & 18.7 \\
\hline $40-49$ & 79 & 21.1 \\
\hline$>50$ & 147 & 39.2 \\
\hline Occupation & & \\
\hline Working Professionals & 240 & 64.0 \\
\hline Student & 58 & 15.5 \\
\hline others (work/study at home) & 77 & 20.5 \\
\hline Education level & & \\
\hline some high school & 173 & 46.1 \\
\hline Graduate degree/professional/PhD degree & 42 & 11.2 \\
\hline
\end{tabular}

\section{SOURCES OF INFORMATION ABOUT EBOLA VIRUS DISEASE}

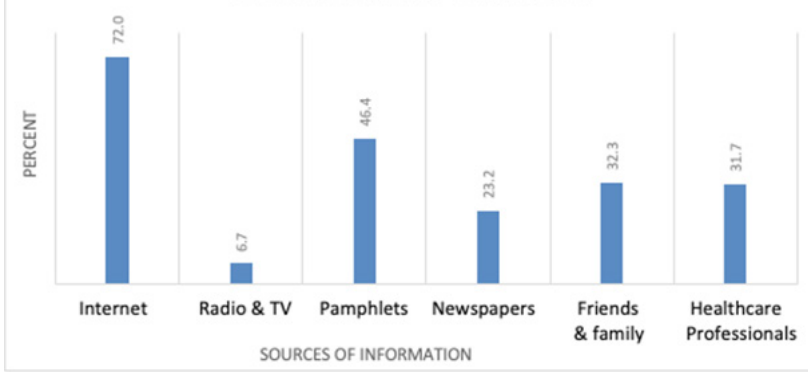

Figure 1: Community Sources of Information Regarding EVD.

degree/ PhD. About half of the individuals completing the survey had a high school degree.

Figure 1 provides a representation of how community members obtained information regarding EVD. Each of the sources could be selected using a select all that apply question, so each of the sources has a possible total percentage of $100 \%$. The most common source of information was internet ( $72 \%$ of respondents) and the least common source of information was TV/Radio (6.7\% of respondents).

Table 2 states that there were a total of 9 questions with correct answers. About $11 \%$ of our participants qualified for having good Ebola knowledge, which was indicated by having a score of 4 and above. Several questions were impacted by demographic factors such as education qualifications, profession and age.

Table 3 shows the results of logistic regression. People aged 50 and above were more likely to have good 


\begin{tabular}{|c|c|c|c|c|c|c|}
\hline \multirow[t]{2}{*}{ Knowledge questions } & \multicolumn{2}{|c|}{ Correct Answers } & \multicolumn{4}{|c|}{$P$ value $^{a}$} \\
\hline & $N$ & $\%$ & Gender & Age & Profession & $\begin{array}{l}\text { Educational } \\
\text { qualification }\end{array}$ \\
\hline How does Ebola spread? & 44 & 11.7 & 0.4791 & 0.6447 & 0.7626 & 0.5709 \\
\hline $\begin{array}{l}\text { What are the classic } \\
\text { symptoms of Ebola? }\end{array}$ & 169 & 45.1 & 0.9156 & 0.0205 & 0.7866 & 0.5623 \\
\hline $\begin{array}{c}\text { Do you think your pet is at risk } \\
\text { of getting Ebola? }\end{array}$ & 255 & 68.0 & 0.2035 & 0.641 & 0.1101 & 0.4728 \\
\hline $\begin{array}{l}\text { Which of the following } \\
\text { precautions should be taken } \\
\text { upon contact with an Ebola } \\
\text { patient? }\end{array}$ & 179 & 47.7 & 0.3375 & 0.0875 & 0.0429 & 0.0797 \\
\hline $\begin{array}{l}\text { If you travel to a country with } \\
\text { an Ebola outbreak, what } \\
\text { foods/animals should you } \\
\text { avoid? }\end{array}$ & 74 & 19.7 & 0.5961 & 0.6092 & 0.02 & $<.0001$ \\
\hline $\begin{array}{l}\text { How often should you monitor } \\
\text { health for possible symptoms? }\end{array}$ & 55 & 14.7 & $0.4953^{b}$ & $0.9111^{\mathrm{b}}$ & $0.1864^{b}$ & $0.0038^{b}$ \\
\hline $\begin{array}{l}\text { Is a vaccine available for } \\
\text { Ebola? }\end{array}$ & 3 & 0.8 & $0.5685^{b}$ & $0.0244^{b}$ & $0.4858^{b}$ & $0.727^{b}$ \\
\hline $\begin{array}{c}\text { Do you think Ebola can cause } \\
\text { death if untreated? }\end{array}$ & 4 & 1.1 & $0.6497^{b}$ & $0.4577^{b}$ & $0.6177^{b}$ & $0.4563^{b}$ \\
\hline $\begin{array}{l}\text { What symptoms may you see } \\
\text { in Ebola infected individuals? }\end{array}$ & 0 & 0.0 & NA & NA & NA & NA \\
\hline
\end{tabular}

${ }^{a}$ Chi Square test was applied. ' $F$ isher's Exact Test was applied when more than $20 \%$ of the cells had expected counts less than 5 .

knowledge of Ebola compared to those aged 18-29 $(\mathrm{OR}=2.77, p<0.05)$. People who received a graduate degree/professional degree/Ph.D were more likely to have good knowledge of Ebola compared to those who had a high school degree $(\mathrm{OR}=6.62, p<0.01)$.

\section{DISCUSSION}

Studies suggest increasing the available amount of information about EVD to the public, mainly focusing on the routes of transmission and myths about survivor infectivity, regardless of incidence of disease may be beneficial to increase the education level of individuals. ${ }^{10-13}$ Kobayashi et al. demonstrated the need to screen the population where the disease is not prevalent, as a few cases in these areas with low disease knowledge could potentially lead to an outbreak. ${ }^{13}$ Of 375 participants, only $11 \%$ were considered to have good knowledge, which is to be expected for an area that has never seen the virus. According to the survey results, the information our populations were most unaware of was about the presence of the Ebola vaccine and how deadly it is left untreated. The information our participants were most aware of were how to avoid infection while in contact with an EVD patient and if their pets were at risk for the disease. These results make sense, as the first set of information is not common intuitive information and the second can be figured out with critical thinking.

From the results of our study, only two demographics stood out as statistically significant for having good knowledge of EVD. These two groups were people 50 years of age or older and those who have completed a graduate level degree, such as a Ph.D or other professional degree. Those who are 50 years of age or older may have had better knowledge due to the generation's preference for more traditional forms of media, such as television and newspaper. While traditional news outlets may not have been enough for EVD education, it may have been more reliable information than many social media sites. The second group, individuals with higher degrees of education, may be more likely to have better knowledge due to their time spent in higher education. To obtain these degrees, people must be able to sort 


\begin{tabular}{|c|c|c|c|c|}
\hline Gender & $\begin{array}{l}\text { Odds } \\
\text { ratio }\end{array}$ & \multicolumn{2}{|c|}{$95 \% \mathrm{Cl}$} & $\begin{array}{c}P \\
\text { value }\end{array}$ \\
\hline Females & ref & ref & ref & ref \\
\hline Male & 1.16 & 0.58 & 2.32 & 0.6861 \\
\hline \multicolumn{5}{|l|}{ Age } \\
\hline $18-29$ & ref & ref & ref & ref \\
\hline $30-39$ & 1.51 & 0.44 & 5.19 & 0.7857 \\
\hline $40-49$ & 0.86 & 0.23 & 3.26 & 0.2216 \\
\hline$>50$ & 2.77 & 0.83 & 9.23 & 0.0214 \\
\hline \multicolumn{5}{|l|}{ Occupation } \\
\hline working professionals & ref & ref & ref & ref \\
\hline student & 1.88 & 0.62 & 5.76 & 0.1028 \\
\hline others & 0.47 & 0.15 & 1.44 & 0.0837 \\
\hline \multicolumn{5}{|l|}{ Education level } \\
\hline some high school & ref & ref & ref & ref \\
\hline $\begin{array}{l}\text { undergraduate degree/ } \\
\text { some college }\end{array}$ & 2.97 & 1.28 & 6.89 & 0.6826 \\
\hline $\begin{array}{c}\text { Graduate degree/ } \\
\text { professional/PhD } \\
\text { degree }\end{array}$ & 6.62 & 2.43 & 18.09 & 0.0015 \\
\hline
\end{tabular}

through data, find relevant information and critically evaluate it. $^{19,20}$ These critical thinking skills are usually part of curricula in Colleges and new methods are consistently researched to improve these critical thinking skills. This group will also contain the highest educated members of the medical field, whose interest in medicine may lead them to do independent research on the subject or complete Continuing Education (CE) on it.

To remedy the lack of knowledge and prevent possible outbreaks, it would be beneficial to provide more education to the general public. One strategy may be to empower healthcare workers to better inform their patients. Our study has shown people with higher degrees of education are more likely to have better knowledge and people generally trust healthcare workers. ${ }^{21,22}$

Another strategy may be to increase the amount of correct information available to the public. Pamphlets in common public venues and seminars may be helpful in this regard. The National Ebola Training and Education Center (NETEC) was established in 2015 in response to large outbreaks of EVD and a primary area that the NETEC was tasked with was developing and providing education materials, resources and tools to improve education on EVD especially among healthcare workers. ${ }^{23,24}$ Utilizing this information and integrating it into public resources may be beneficial in the future

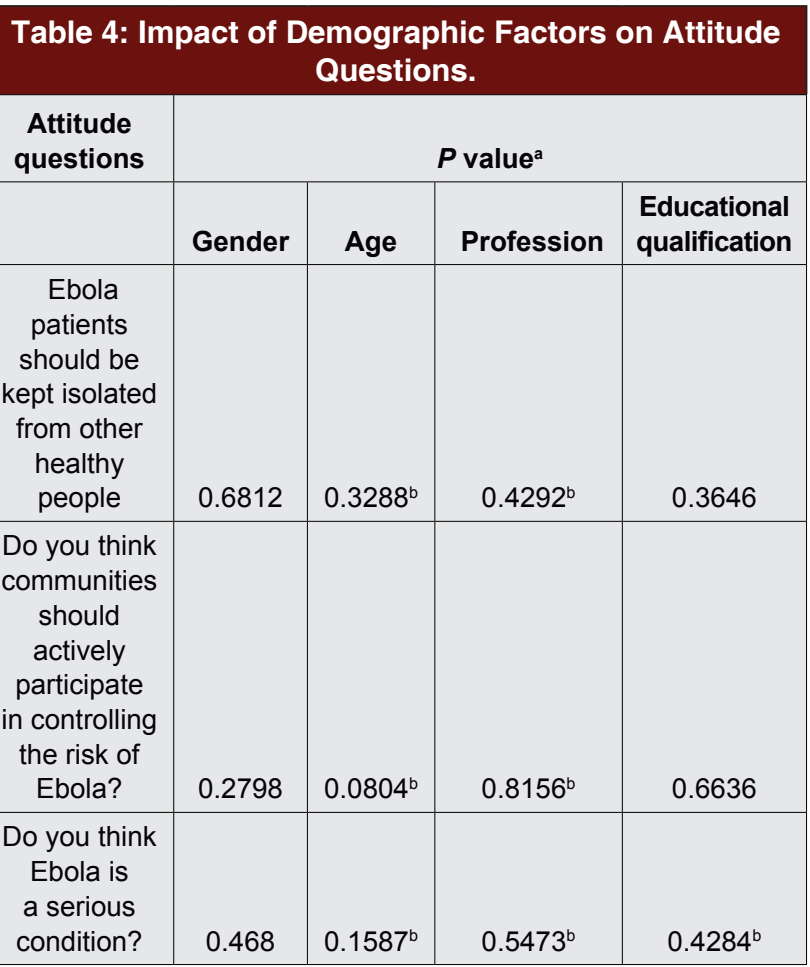

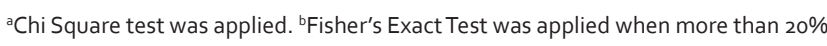
of the cells had expected counts less than 5 . Attitude was assessed by giving 1 to $S D, 2$ to $D, 3$ to $A, 4$ to $S A$

to help educate members of the public. As previously discussed, this information can also help improve healthcare workers' knowledge which may be able to then be passed on during patient education.

\section{Limitation}

One of the largest limitations of our study is the small sample size. We only received 375 complete responses and only one area was surveyed, which may limit generalizability to other areas. In addition, since this was an observational design using a survey method causal inferences cannot be made. There is also a chance of recall bias depending on information remembered by the participants in the study.

\section{CONCLUSION}

Overall our results showed that individuals $>50$ years old and with a larger educational background scored higher on their knowledge of EVD when compared to other groups of community participants. Further studies performed in multiple areas may be beneficial in assessing the larger population's knowledge of EVD. This study has shown that a small number of community participants are knowledgeable about EVD. Thus, further engagement and education of the community may be beneficial to help reduce the risk of EVD in the future. 


\section{ACKNOWLEDGEMENT}

None.

\section{CONFLICT OF INTEREST}

The authors declare that they have no competing interests.

\section{ABBREVIATIONS}

EVD: Ebola Virus Disease; CE: Continuing Education; NETEC: National Ebola Training and Education Center.

\section{REFERENCES}

1. CDC. Ebola (Ebola Virus Disease). CDC. 2018 [cited 2018 Nov 12]. Available from: https://www.cdc.gov/vhf/ebola/index.html.

2. CDC. Signs and Symptoms Ebola Hemorrhagic Fever. CDC. 2018. [cited 2018 Nov 12]. Available from: https://www.cdc.gov/vhf/ebola/symptoms/ index.html.

3. CDC. Transmission Ebola Hemorrhagic Fever. CDC. 2018. [cited 2018 Nov 12]. Available from: https://www.cdc.gov/vhf/ebola/transmission/index.html.

4. CDC. Treatment Ebola (Ebola Virus Disease). CDC. 2018. [cited $2018 \mathrm{Nov}$ 12]. Available from: https://www.cdc.gov/vhf/ebola/treatment/index.html.

5. World Health Organization. Frequently Asked Questions. WHO; [cited 2019 Apr 10]. Available from: https://www.who.int/ebola/drc-2018/faq-vaccine/en/

6. CDC. Years of Ebola Virus Disease Outbreaks 2014-2016 Outbreak West Africa History Ebola (Ebola Virus Disease). CDC. 2018. [cited 2018 Nov 12]. Available from: https://www.cdc.gov/vhf/ebola/history/chronology.html.

7. Smith T. Chekhov's Corner Ebola as a course: uniting basic sciences, public health and the humanities. Journal of Public Health. 2015;38(4):592-5. Available from: https://academic.oup.com/jpubhealth/article/38/4/e592/2966933

8. Towers S, Afzal S, Bernal G, et al. Mass Media and the Contagion of Fear: The Case of Ebola in America. PLoS One. 2015;10(6):e0129179. Available from: https://journals.plos.org/plosone/article/file?id=10.1371/journal.pone. 0129179\&type=printable

9. Odlum M, Yoon S. Health Information Needs and Health Seeking Behavior during the 2014-2016 Ebola Outbreak: A Twitter Content Analysis. PLoS currents. 2018;10. Available from: https://www.ncbi.nlm.nih.gov/ pubmed/29707416

10. Ahmad A, Khan MU, Jamshed SQ, et al. Are Healthcare Workers Ready for Ebola? An Assessment of Their Knowledge and Attitude in a Referral Hospital in South India. J Infect Dev Ctries. 2016;10(7):747-54. Available from: https:// www.ncbi.nlm.nih.gov/pubmed/27482807

11. Ilesanmi O, Alele FO. Knowledge, Attitude and Perception of Ebola Virus Disease among Secondary School Students in Ondo State, Nigeria, October, 2014. PLoS Curr. 2016;8. Available from: 10.1371/currents.outbreaks. c04b88cd5cd03cccb99e125657eecd76
12. Nyakarahuka L, Skjerve E, Nabadda D, et al. Knowledge and attitude towards Ebola and Marburg virus diseases in Uganda using quantitative and participatory epidemiology techniques. PLoS Negl Trop Dis. 2017;11(9):e0005907. Available from: https://www.ncbi.nlm.nih.gov/ pubmed/28892520

13. Kobayashi M, Beer K, Bjork A, et al. Community Knowledge, Attitudes and Practices Regarding Ebola Virus Disease-Five Counties, Liberia, SeptemberOctober. 2014. MMWR. 2015;64(26):714-8.

14. Jones KTEC, Murakami A, Sasaki $\mathrm{H}$, et al. Intensive Education of Health Care Workers Improves the Outcome of Ebola Virus Disease: Lessons Learned from the 2014 Outbreak in Sierra Leone. Tohoku J Exp Med. 2017;243(2):101-5. Available from: https://www.jstage.jst.go.jp/article/ tjem/243/2/243_101/_pdf/-char/en

15. Shrivastava S, Shrivastava P, Ramasamy J. Public health strategies to ensure optimal community participation in the Ebola outbreak in West-Africa. J Res Med Sci. 2015;20(3):318-9. Available from: https://www.ncbi.nlm.nih. gov/pmc/articles/PMC4468240/\#ref3

16. Frieden T, Damon I, Bell B, et al. Ebola 2014 - New Challenges, New Global Response and Responsibility. NEJM. 2014;371(13):1177-80. Available from: https://www.nejm.org/doi/10.1056/NEJMp1409903?url_ver=Z39.882003\&rfr_id=ori:rid:crossref.org\&rfr_dat=cr_pub\%3dwww.ncbi.nlm.nih.gov

17. Chan M. Ebola Virus Disease in West Africa - No Early End to the Outbreak. NEJM. 2014;371(13):1183-5. Available from: https://www.nejm.org/ doi/10.1056/NEJMp1409859?url_ver=Z39.88-2003\&rfr_id=ori:rid:crossref. org\&rfr_dat=cr_pub\%3dwww.ncbi.nlm.nih.gov

18. Patel I, Guy, J, Han Y, et al. Effects of Ebola Virus Disease education on student health professionals. Curr Pharm Teach Learn. 2018;10(5):651-6.

19. Brownwell SE, Hekmat-Scafe DS, Singla V, et al. A high-enrollment course-based undergraduate research experience improves student conceptions of scientific thinking and ability to interpret data. CBE Life Sci Educ. 2015;14(2):14-21. Available from: https://www.ncbi.nlm.nih.gov/ pubmed/26033869

20. Kanbay $Y$, Okanli A. The effect of critical thinking education on nursing students' problem-solving skills. Contemp Nurse. 2017;53(3):313-21. Available from: https://www.ncbi.nlm.nih.gov/pubmed/28589781

21. Brenan M. Nurses Keep Healthy Lead as Most Honest, Ethical Profession. Gallup. [cited 2019 Apr 10]. Available from: https://news.gallup.com/ poll/224639/nurses-keep-healthy-lead-honest-ethical-profession.aspx?g_ source=Economy\&g_medium=newsfeed\&g_campaign=tiles

22. Mccarthy N. America's Most \& Least Trusted Professions. Forbes. [cited 2019 Apr 10]. Available from: https://www.forbes.com/sites/ niallmccarthy/2019/01/11/americas-most-least-trusted-professionsinfographic/\#64a3a2647e94

23. Kratochvil CV, Evans L, Ribner BS, et al. The National Ebola Training and Education Center: Preparing the United States for Ebola and Other Special Pathogens. Health Secur. 2017;15(3):253-60. Available from: https://www. ncbi.nlm.nih.gov/pubmed/28636442

24. National Ebola Training and Education Center. About NETEC [. [cited 2019 Apr 10].

\section{SUMMARY}

Educating individuals in the community is an important step in helping to improve response to disease outbreaks. The results of this study showed that higher age and education level were associated with more knowledge regarding the Ebola virus. Only $11 \%$ of community patients met the study's classification of having good knowledge of the Ebola Virus. The low number of patients with a good knowledge of the Ebola virus presents challenges to help better educate and engage the community at large. 




Cite this article: Patel I, Jennings T, Han Y, Guy J, Onigbinde I, Kwarteng E, Eppes D, Parker D, Johnson M. Knowledge and Attitudes about Ebola Virus Disease among Community Residents in Winchester, Virginia, US. Indian J of Pharmaceutical Education and Research. 2019;53(3):562-8. 